\title{
回転慣性質量を利用したTMD による上下動制振に関する実験的研究 EXPERIMENTAL STUDY ON VERTICAL VIBRATION CONTROL BY A TMD USING A ROTATING INERTIA MASS
}

\author{
半澤徹 也*, 磯田和彦* \\ Tetsuya HANZAWA and Kazuhiko ISODA
}

\begin{abstract}
A tuned mass damper (TMD) using a rotational inertia mass has been developed to reduce vertical vibrations of beams and slabs subjected to walking excitations and earthquake motions. The newly developed TMD is composed of a spring and a ball screw mechanism with a fly wheel. Vibration tests of a beam structure were carried out to show the effectiveness of the TMD using a rotational inertia mass and compare the test results with those of simulation analyses using a theoretical model.
\end{abstract}

Keywords : Rotating inertia mass, Vertical vibration control, Beam vibration, Tuned mass damper 回転慣性質量, 上下動制振, 梁振動, 同調質量減衰器

\section{1.はじめに}

大スパンを有する構造物では，人間の歩行による振動で居住者が 不快感を感じたり，地震による積載物の飛び跳ね，転倒落下といっ た問題が生じる場合がある。このような大スパン梁の上下振動を抑 制するため, 梁に制振機構を付加する方法がある。制振機構として

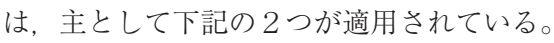

(1)梁のたわみに伴って変形する部分に粘性減衰(粘弾性ダンパー) を付加する ${ }^{1)}$

(2)たわみ振幅の大きい箇所にTMD（動吸振機構）を設置する2)

(1)の方法は振動数の依存性が少ない減衰特性を付加できるが, ダ ンパーの変形量が小さいために振動低減効果は概して小さい。一 方，(2)の方法は共振振動数近傍の振動を効果的に抑制できるが, TMD の精緻な同調作業が必要である。同調比に対するロバスト性 を向上させるには，質量比を大きくして適切な減衰定数を設定する 必要があるが，主構造への荷重負担が増加する問題がある。これに 対して森田・石丸ら ${ }^{3)}$ は, 梁中央部下側に補助質量を設け, 梁と卜 グル機構を介して接続した張弦梁構造（TSS）を提案し, 振動理論 と解析により比較的小さな補助質量で大きな制振効果が得られると している。

トグル機構以外の変位拡大機構としてはボールねじ機構がある。 ボールねじ機構はコンパクトで変位の拡大率も大きく，これを利用
した慣性質量ダンパー（慣性接続要素）が研究されている。柴田, 奥村ら ${ }^{4)}$ は, 特定振動数の振動を伝達しない「振動遮断装置」をこ の慣性質量ダンパーと並列ばねで構成し，それを応用した免制震構 造を提案している。また, 柳崎, 石丸ら ${ }^{5)}$ は慣性質量ダンパーを免 震装置と並列配置させた変位抑制型免震機構を開発している。一 方, この慣性質量ダンパーと付加ばねを直列にして, 構造体ばねに 並列に配置した場合は，TMD と同様に特定の振動数で振動を抑制 する効果がある。斉藤ら ${ }^{6) ~ 8)}$ は定点理論から 1 質点系の最適応答制 御の条件を明らかにしている。松岡・砂子田 ${ }^{9}$ はボールねじを用い た磁気ダンパーとばねを直列にした装置で変位伝達関数を求め最適 条件を示している。また, 関根, 栗田 ${ }^{10)}$ はインパルス応答の二乗平 均值平方根 (RMS) を用いて1 質点系の最適設計法を提案している。

本論文は，ボールねじ機構を利用することで，小さな錘の質量で 大きな TMD 効果が得られることに着目して, 慣性質量ダンパーを 梁の上下動制振に応用しょうとしたものである。梁の上下振動は, 構造物の水平方向の振動に比べて卓越振動数が高く, 振幅が小さい。 また, 実際のボールねじ機構には摩擦などの内部抵抗が避けられな い。そのために本研究では, 実大のボールねじ機構を用いた振動実 験を行い, 理論と照合するとともに摩擦などの内部抵抗をモデル化 した。さらに, 実構造物の梁に制振機構を適用した場合の振動低減 効果を時刻歴応答解析により検討した。なお，提案する梁の上下制 
振機構は, ボールねじ機構と減衰機構と付加ばねから構成されるが, 本論文では，減衰機構を設けていない実大ボールねじ機構を対象と して振動実験とモデル化を行っている。

\section{2. ボールねじ機構と慣性質量効果}

図 1 にナット回転型のボールねじ機構を示す。ボールナットは回 転自在，軸方向変位を拘束とし，ボールねじは軸方向変位を自在， 回転拘束としている。ボールねじとボールナットの間には鋼球が介 在し, ボールねじの直動変位に対して, ボールナットに回転運動が 生じる。摩擦等の抵抗がなければ，運動の変換に静的な抵抗は生じ ないが，ボールナットにはフライホイール（回転錘）が一体化され ており,この回転角速度の変化によって, 動的な慣性抵抗が生じる。

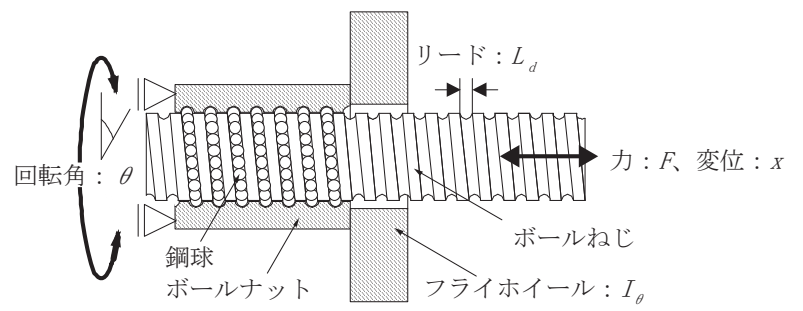

図 1 ボールねじ機構

ボールねじの変位 $x$ により, 回転慣性モーメント $I_{\theta}$ をつフラ イホイールを $\theta$ 回転させたときの慣性抵抗力 $F$ とする。ボールね じのリード（ねじ山ピッチ） $L_{d}$, フライホイールを円盤状として径 $D$, 質量 $m$ とすると， $x=\theta L_{d} /(2 \pi)$ から次式が成立する。

$$
F=\frac{I_{\theta} \ddot{\theta}}{L_{d} /(2 \pi)}=\left(\frac{2 \pi}{L_{d}}\right)^{2} I_{\theta} \ddot{x}=\frac{\pi^{2} D^{2}}{2 L_{d}^{2}} m \ddot{x}=\psi \ddot{x}
$$

上式の $\psi$ が直動方向の慣性質量であり, 回転錘の質量 $m$ の数百 倍〜数千倍の值に拡大される。上式より，この反力は直動方向の加 速度（ボールねじとボールナットとの間の相対加速度） $\ddot{x} に$ 比例す ることがわかる。この慣性質量を TMD 機構の錘として利用すれば, 小さな回転錘でも大きな慣性質量効果が得られるため, 梁への重量 負荷を増さずに大きな制振効果が期待できる。

本論文で対象とする制振機構を図 2 に例示する。梁の中央部に付 加ばねを介して慣性質量と減衰機構を設置し，下階の床から支柱で 接続する形態と，梁の両端との間に下弦材による付加ばねを介し て, 慣性質量と減衰機構とを梁に接続する形態である。慣性質量お よび直列に配した付加ばねからなる付加振動系の固有振動数を, 構 造梁の固有振動数と同調させることにより, TMD 機構となる。な お，いずれの形態も力学的には図 3 のようにモデル化される。構造 体に調和加振力 $F=f_{0} e^{i \omega t}$ を受ける場合の振動方程式は次式となる。

$$
\begin{aligned}
& M \ddot{X}+C \dot{X}+K X+P=f_{0} e^{i \omega t} \\
& P=\psi \ddot{x}_{d}+c_{d} \dot{x}_{d}=k_{d}\left(X-x_{d}\right)
\end{aligned}
$$

ここで, $X$ : 構造体変位 (複素振幅表現) $, x_{d}:$ ダンパー変位, $M$ : 構造体質量, $K$ : 構造体剛性, $C$ : 構造体粘性減衰係数, $\psi$ : 慣性質 量, $c_{d}$ : ダンパーの粘性減衰係数, $k_{d}$ : 付加ばね剛性である。この 系の動的応答倍率は次式の絶対值 $\left|X / X_{s t}\right|$ で表される。

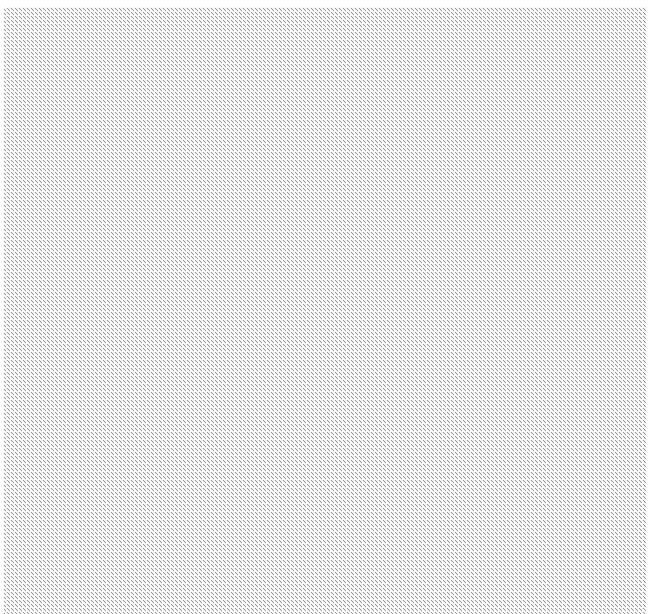

図 2 提案する制振機構の設置例

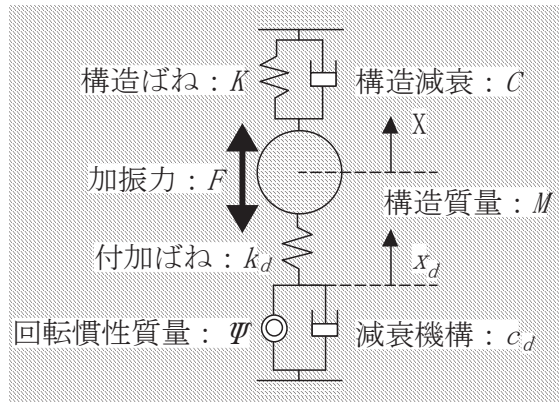

図３制振機構を設置した構造体の力学モデル

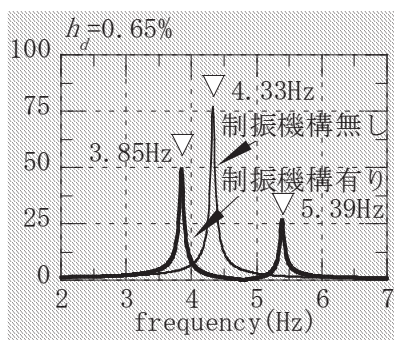

図 4 床板の応答倍率

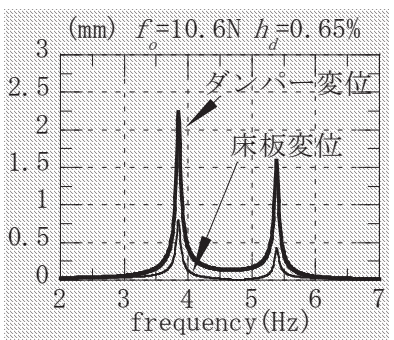

図 5 ダンパー変位と床板変位

$$
\frac{X}{X_{s t}}=\frac{1}{1-\xi^{2}+2 h \xi i+\frac{\eta^{2}\left(-\xi^{2}+2 h_{d} \eta \xi i\right)}{\eta^{2}-\xi^{2}+2 h_{d} \eta \xi i} \mu}
$$

ここで, $X_{s t}=f_{0} / K$ : 構造体の静的変位, $\xi=\omega / \omega_{0}$ : 加振円振動数 と構造体固有円振動数との比, $\eta=\omega_{d} / \omega_{0}$ : ダンパー系の固有円振 動数と構造体固有円振動数との比, $h=C /\left(2 M \omega_{0}\right)$ : 構造体の減衰定 数, $i$ : 虚数単位, $h_{d}=c_{d} /\left(2 \psi \omega_{d}\right)$ : ダンパー系の減衰定数, $\mu=\psi / M$ : 質量比, $\omega_{0}=\sqrt{K / M}$ : 構造体の固有円振動数, $\omega_{d}=\sqrt{k_{d} / \psi}$ : ダン パー系の固有円振動数である。また, ダンパー変位（複素振幅表現） は次式となる。

$$
x_{d}=\frac{\eta^{2}}{\eta^{2}-\xi^{2}+2 h_{d} \eta \xi i} X
$$

計算例として, 後述の実験加振装置の動的応答倍率（調和加振時 の床板の静的変位に対する動的変位の比）を図 4 に, 床とダンパー の変位を図 5 に示す $\left(h=h_{d}=0.0065\right)$ 。ボールねじ機構が無いと, 床板は固有振動数 $(4.33 \mathrm{~Hz})$ で共振するが, ボールねじ機構を共振

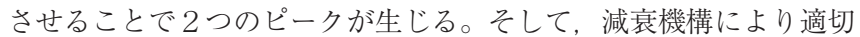




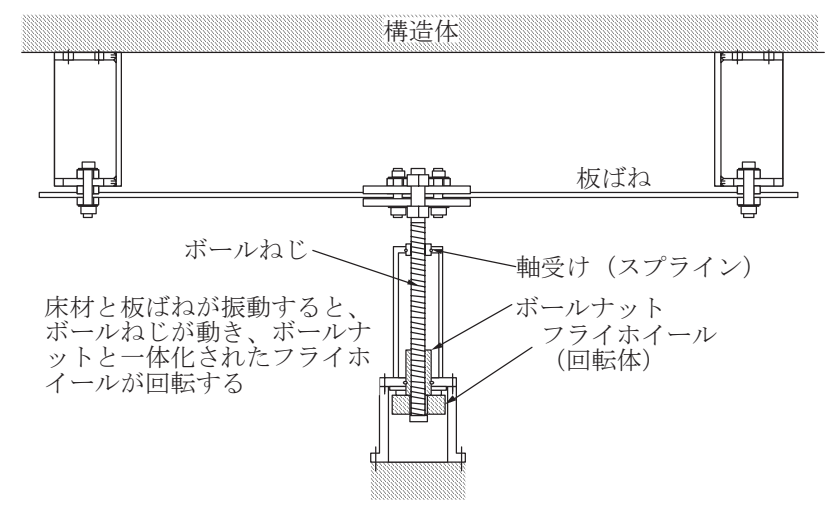

図 6 ボールねじ機構

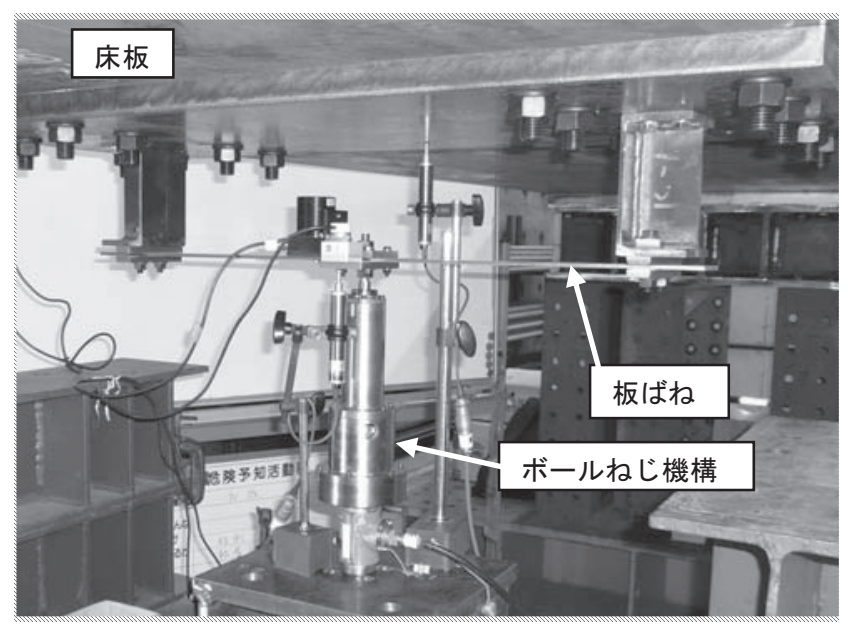

写真 1 ボールねじ機構

な減衰定数を設定すれば, そのピーク高さを低くすることができる。 また, ダンパーの変位は約 $3.5 \mathrm{~Hz} \sim 5.5 \mathrm{~Hz}$ の範囲（共振域）で床板 の変位よりも大きくなることがわかる。

\section{3. 実験内容}

\section{1 試験体}

図 6 に支柱形態に適用した場合のボールねじ機構を示す。ボール ねじが上下 2 力所で軸受け（鉛直方向は自由）され，さらに板ばね に固定されたもので，板ばねの変位によりボールねじが上下方向に 変位するとボールナットが回転する。ボールナットにはフライホ イールが固定され, 慣性質量効果が得られる。本研究の実験では, ボールねじのリードを 5 と10とした 2 体の試験体を用意した。

\section{2 加振装置と加振方法}

加振装置を図 7 に, ボールねじ機構の周囲を写真 1 に示す。幅 $5 \mathrm{~m}$, 奥行き $1.3 \mathrm{~m}$, 厚さ $25 \mathrm{~mm}$ の鋼板に, 質量を付加するために $1100 \times 550 \times 32 \mathrm{~mm}$ の鋼板 2 枚をボルトで固定し, 両端を治具で固 定したものを構造床板とした。その中央部直下に制振機構を設置し て, その直上に設置した起振器により加振し, 制振機構の有無によ る振動性状の違いを検討した。加振装置の諸元を表 1 に示す。床板 および板ばねのばね剛性は実測值, 床板の固有振動数は加振実験結 果から得られた值である。床板の有効質量はばね剛性と固有振動数 から求めた值である。フライホイールの慣性質量（計算值）は，床 板の有効質量の $9.4 \%$ であり, 実際の質量の 237 倍（リード10の場合）

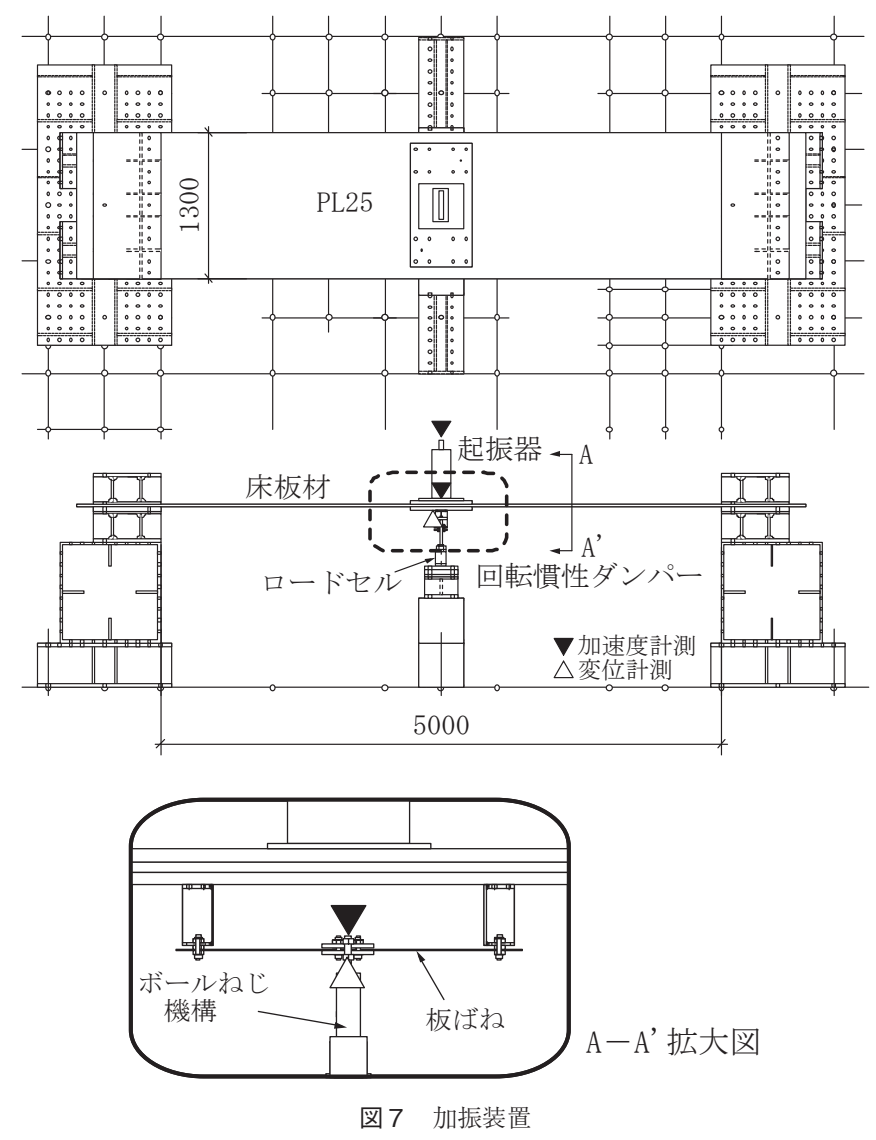

表 1 諸元

\begin{tabular}{|c|c|c|}
\hline 床板剛性(N/m) & \multicolumn{2}{|c|}{$6.61 \times 10^{5}$} \\
\hline 床板振動数 $(\mathrm{Hz})$ & \multicolumn{2}{|c|}{4.33} \\
\hline 有効質量(kg) & \multicolumn{2}{|c|}{893.1} \\
\hline 板ばね剛性(N/m) & \multicolumn{2}{|c|}{$7.62 \times 10^{4}$} \\
\hline \multicolumn{3}{|c|}{ フライホイール } \\
\hline リード & 慣性質量 $(\mathrm{kg})$ & 寸法 $(\mathrm{mm})$ と実質量 $(\mathrm{kg})$ \\
\hline リード5（N05) & 84.1 & $\mathrm{D}=49, \mathrm{t}=12, \mathrm{~m}=0.178$ \\
\hline リード10 (N10) & 84.1 & $\mathrm{D}=69, \mathrm{t}=12, \mathrm{~m}=0.355$ \\
\hline
\end{tabular}

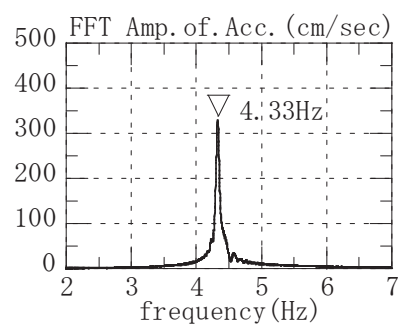

図8 床のみの加速度 Fourier 振幅

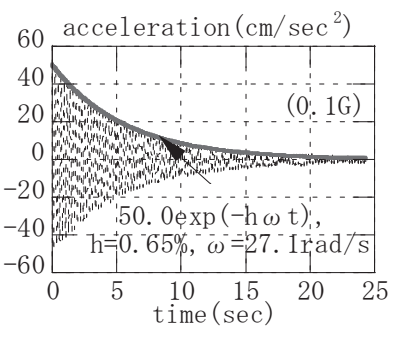

図9床のみの自由振動
および472倍（リード 5 の場合）となっている。計測は, 床板中央 部および試験体板ばねの中央部の加速度および変位, 起振器可動部 の加速度, および試験体下端に設置したロードセルによる荷重值で ある。加振方法は, 加速度一定 sweep 加振 $(1.5 \mathrm{~Hz} \sim 7.0 \mathrm{~Hz}$, 掃引 時間一方向 8 分）㧍よび正弦波加振（加速度, 振動数一定加振, 共 振振動数付近で 1 振動数あたり 2 分程度）である。計測のサンプリ ング振動数は $200 \mathrm{~Hz}$ である。 

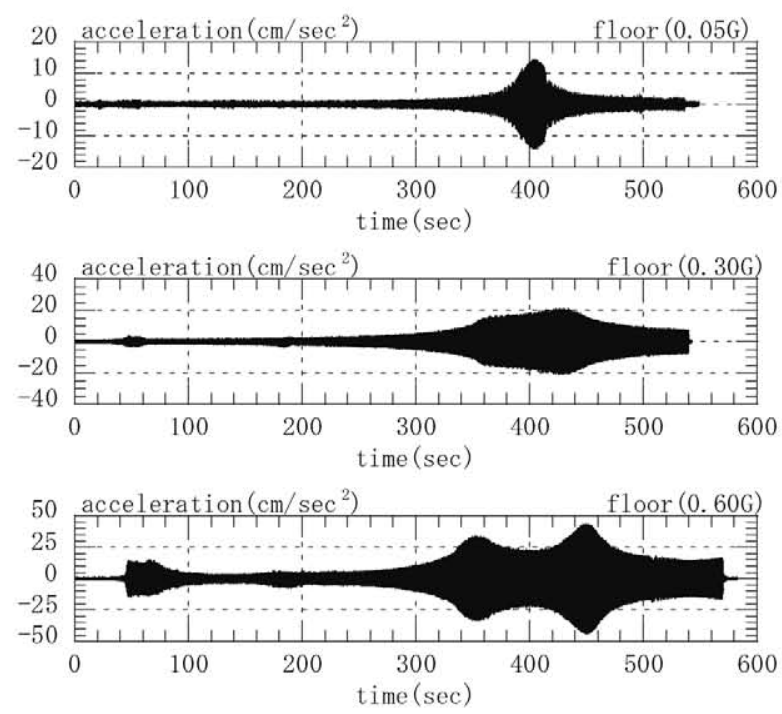

図10 sweep 加振時床板加速度（リード5）

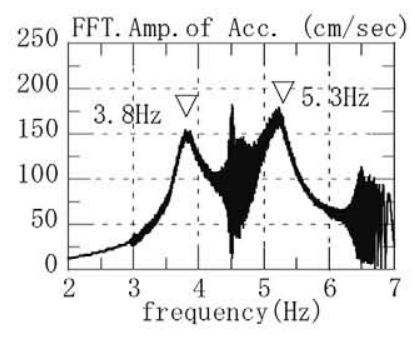

図11 加速度の Fourier 振幅 (リード $5,0.60 \mathrm{G})$

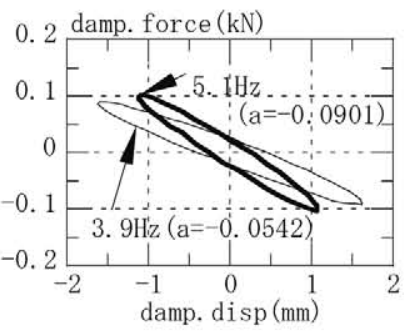

図12 ダンパーの荷重変位関係 (リード $5,0.60 \mathrm{G})$

\section{4. 実験結果}

\section{1 試験体を設置していない床板のみの振動性状}

図 8 に sweep 加振（加振レベル $0.05 \mathrm{G}$, 加振力 $=0.05 \times 10.8 \mathrm{~kg} \times$ $9.8 \mathrm{~m} / \mathrm{sec}^{2}=5.3 \mathrm{~N}, \quad 10.8 \mathrm{~kg}$ は可動部質量）時の床板加速度波形の Fourier 振幅を, 図 9 に正弦波加振 $(4.4 \mathrm{~Hz}$, 加振レベル0.1G) を急 止させた時の自由振動波形を示す。Fourier 振幅のピーク值は $4.33 \mathrm{~Hz}$ となっている。固有振動数付近の自由振動波形の包絡線から，減衰 定数は $0.65 \%$ と推定される。なお, Fourier 振幅は刻み時間 0.005 秒, デー夕数108800の原データを用いて, 文献11）のプログラム FAST によるFFT 值に刻み時間を掛けた值とした（図11，図14も同様）。

4.2 リード 5

図10に sweep 加振時の床の加速度波形を示す。図 4 によれば床 の固有振動数の左右にピークが発生するはずであるが，入力レベル が小さいうちはそれらはみられない。入力レベルを上げて $0.6 \mathrm{G} の$ 場合になると，2つのピークが顕在化している。その場合の Fourier 振幅を図11に示す。ピーク值は $3.8 \mathrm{~Hz}$ と $5.3 \mathrm{~Hz}$ に現れてお り, 図 4 とほぼ一致している。0.6G レベルで正弦波加振を行い, $3.9 \mathrm{~Hz}$ 抢よび $5.1 \mathrm{~Hz}$ における慣性質量ダンパーの荷重変形関係 (ボー ルナット変位とロードセルの荷重值）を図12に示す。式(2)から明ら かなように，ダンパーの荷重は慣性力に応じたもので，データから 最小自乗法により算出される一次直線の傾き（図中 $\mathrm{a}$ 值）は負勾配 となっており，その大きさはほぼ振動数の二乗に比例している。ま た，減衰機構を設けていないが荷重変形関係は閉ループを描いてい る。ダンパーの変位＝0における切片荷重の平均はそれぞれ約 0.0232
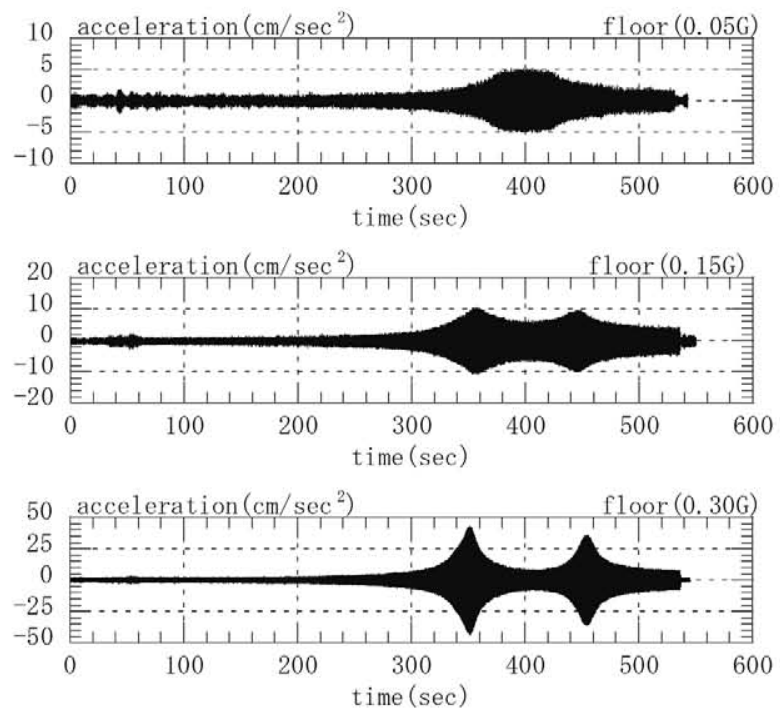

図13 sweep 加振時床板加速度（リード10）

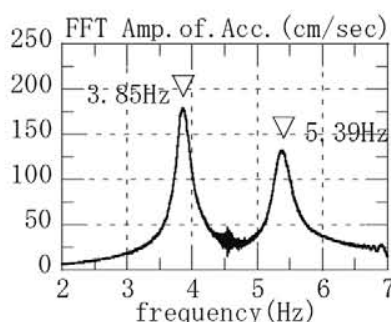

図14 加速度の Fourier 振幅 (リード10, 0.30G)

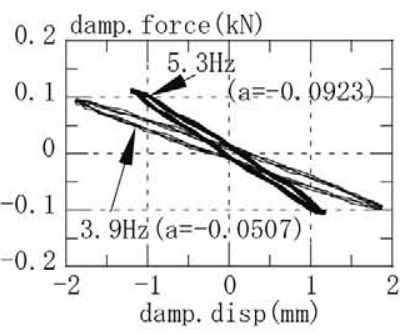

図15 ダンパーの荷重変位関係 (リード10, 0.30G)
$\mathrm{kN}, \quad 0.0237 \mathrm{kN}$ であった。

\section{3 リード 10}

図13に sweep 加振時の床の加速度波形を示す。リード10では, 入力レベルが $0.1 \mathrm{G}$ から 2 つのピークが生じ始め, $0.15 \mathrm{G}$ では顕在化 している。入カレベルが $0.3 \mathrm{G}$ の場合の Fourier 振幅を図 14 示す。 ピーク值は $3.85 \mathrm{~Hz}$ と $5.39 \mathrm{~Hz}$ に現れている。0.3Gレベルで正弦波加 振を行い, $3.9 \mathrm{~Hz}$ および $5.3 \mathrm{~Hz}$ のダンパーの荷重変形関係を図 $15 に$ 示す。リード 5 の場合と同様, データから最小自乗法により算出さ れる一次直線の傾き（図中 $\mathrm{a}$ 值）はほぼ振動数の二乗に比例してい る。また，減衰機構を設けていないが荷重変形関係は閉ループを描 いており, ダンパーの変位＝0における切片荷重の平均はそれぞれ 約 $0.0109 \mathrm{kN}, 0.0111 \mathrm{kN}$ であった。

\section{5. ボールねじ機構（リード10）の内部抵抗}

前節の実験結果では，リード 5 よりもリード10の方が小さな入力 レベルから作動した。これは、リード10の方がボールねじの溝の勾 配が大きいために，ボールと溝との間の摩擦や潤滑剂による抵抗が 小さいためと考えられる。手動でも，リード10の方がリード5より も遙かに軽く感じられた。そこで, 以下ではリード10を対象に解析 との整合性について検討する。入力レベルが大きくならないと $2 つ$ のピークが現れないことや, ダンパーの荷重変形関係に閉ループが 見られることから, 非線形の抵抗があるものと思われる。すなわち, 入力レベルに関わらず実験データを説明するには, 非線形減衰モデ ルが必要になる。この抵抗を鋼球と溝の間の摩擦や潤滑剂によるも 

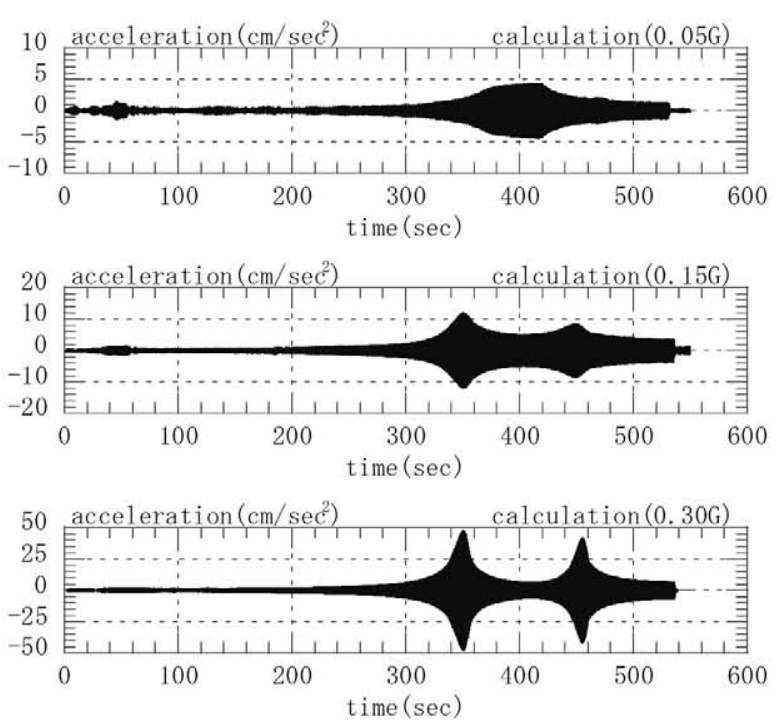

図 17 sweep 加振時床板加速度（リード 10、解析）

のと考え, 眓16のような摩擦ばねとダッシュポットをボールねじ機 構に付加したモデルを仮定した。このうち $\mathrm{p}_{0}$ はデジタル荷重計を 用いて準静的にボールねじを押すことにより，概算值を得た。 $\mathrm{k}_{0}$, $\mathrm{c}_{\mathrm{o}}$ は $0.05 \mathrm{G}, \quad 0.1 \mathrm{G}, \quad 0.15 \mathrm{G}, \quad 0.2 \mathrm{G}, \quad 0.3 \mathrm{G}$ の sweep 加振時の応答加速 度掞よび変位波形と正弦波加振共振時のダンパーの荷重変形関係が 整合するようにパラメトリックスタデイを行って求めた。その結果, リード10のボールねじ機構のモデルを表 2 のように設定した。

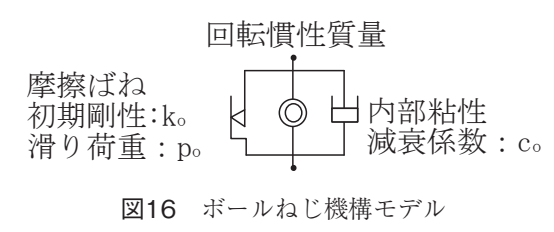

表 2 ボールねじ機構モデルの諸元

\begin{tabular}{|l|l|}
\hline$k_{o}$ & $1 \times 10^{3}(\mathrm{~N} / \mathrm{mm})$ \\
\hline$p_{o}$ & $2.7(\mathrm{~N})$ \\
\hline$c_{o}$ & $90 \mathrm{~N} / \mathrm{m} / \mathrm{s}$ \\
\hline
\end{tabular}

なお，解析は 3 節の周波数領域の解析ではなく, sweep 加振時の 起振器可動部の加速度に可動部質量を乗じた值を加振力として, 時 刻歴応答解析で行った。慣性質量要素は節点間の相対加速度に対し て慣性力を生じるようにモデル化される ${ }^{12)}$ 。

図17に床板の加速度波形を示す。解析波形は図13の実験波形をよ く説明していることがわかる。図18に正弦波加振による床板の加速 度と変位の最大值を示す。解析は $0.1 \mathrm{G}, 0.2 \mathrm{G}, 0.3 \mathrm{G}$ の入力レベル に対して $0.05 \mathrm{~Hz}$ ピッチで行っている。図 $19 に 3.9 \mathrm{~Hz}$ の正弦波加振 $(0.1 \mathrm{G}, 0.2 \mathrm{G}, \quad 0.3 \mathrm{G})$ におけるダンパーの荷重変形関係の比較を示 す。これらにおいても, 解析は実験值をよく説明しているといえる。 荷重変形関係の推移から, 入力レベルの増大に伴いループは扁平 となり，ボールねじ機構の内部抵抗による減衰の影響が小さくなっ てゆくこと, それによって sweep 加振では 2 つのピークが顕在化 し始め，3節の理論と整合するものと考えられる。

図20に正弦波加振（加振レベル0.1G，0.3G）を急止させた時の自 由振動波形を示す。床のみの場合の図 9 と比較すると, いずれも振
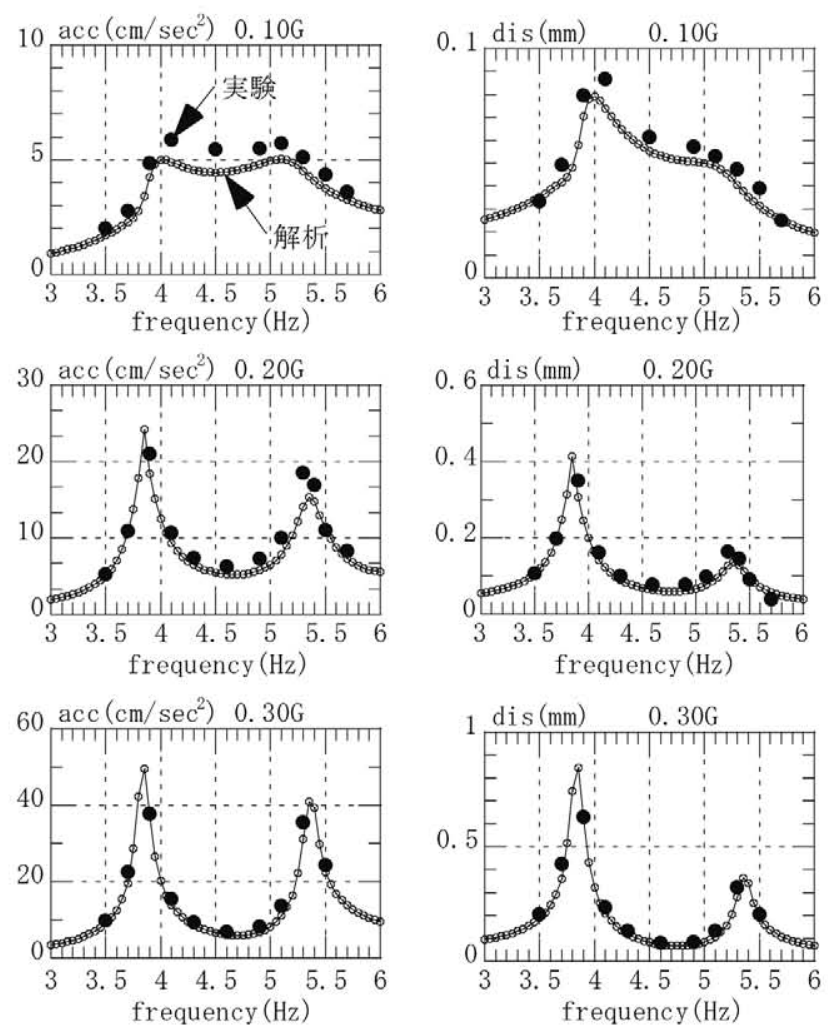

図 18 正弦波加振時床中央の最大加速度・変位（リード 10）
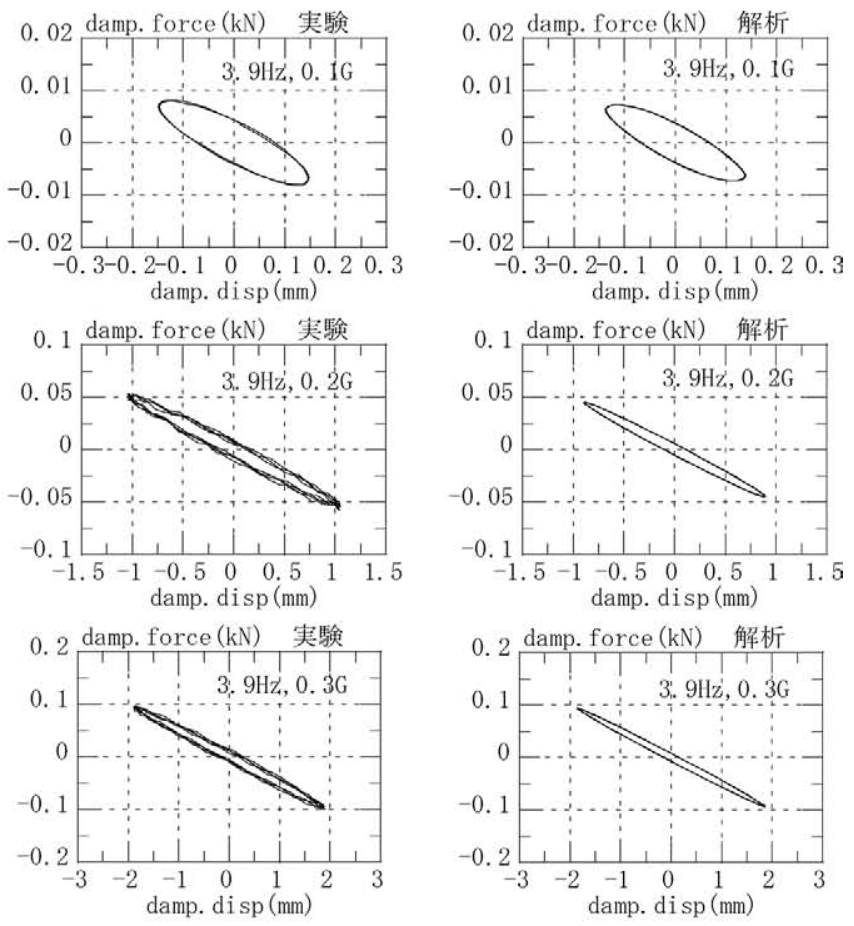

図 19 正弦波 (3.9Hz) 加振時荷重変形関係（実験と解析）

動は急激に収束している。この減衰は振幅に依存しており, 包絡線 から減衰定数を概算すると, それぞれ約 $10 \%, 3 \%$ 程度となる。減 衰が大きい TMD 機構では構造物の自由振動を短時間で収束し,「後 摇れ」への効果が期待できると思われる。これは次節で検討する。 なお，表 2 の諸元は実験で用いた慣性質量に基づくものであり， より大きな慣性質量を用いる場合には別途検証が必要と考えられ る。 

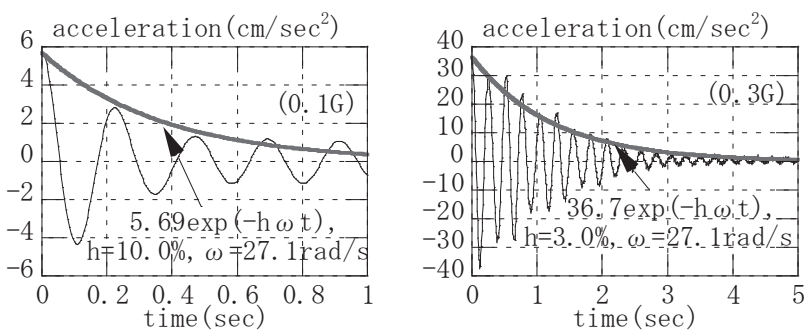

図20 加振レベル0.1Gと0.3G における自由振動

\section{6. 実大梁に対するシミュレーション解析}

\section{1 歩行荷重に対する検討}

本節では, 前節の解析モデルを用いて, 実際の梁・床を対象とし て歩行および地震動に対するシミュレーション解析を行い, 付加制 振機構の実用性に関する検討を行う。

構造体は床スラブ付きの梁を想定する。構造体と解析モデルを図 21 に示す。平成12年告示1459号によれば，建物の使用上の支障が生 じないための条件は，長期荷重による撓み角が $1 / 250$ 以下である。 図 21 の構造体は，静的撓み角が $1 / 910<1 / 250$ となっており，告示 の規定を満足している。次に, 外乱と諸元は以下のように設定する。 ・床梁の断面 2 次モーメント : $\mathrm{I}=2 \times 274760=549530 \mathrm{~cm}^{4}$ 。周期の 変動を考慮したケースとして $2 / 3$ 倍，1.5倍も追加し，G0, G1， G2モデルと表す。

·構造質量 : 集中質点系では, 有効質量は $0.6 \times 3.6 \times 16.5 \times 0.49=$ $17.46 \mathrm{t}$ だが，解析モデルは梁を20分割して19質点系とする。各質 点の質量は1.782t とする。固有值解析結果を表 3 に示す。

·外乱：文献13）の歩行荷重を, 梁中央質点に加振力として与える。 歩行荷重波形と Fourier 振幅を図 22 に示す。卓越振動数は $1.86 \mathrm{~Hz}$ であるが, 実際の外乱の卓越振動数は一人歩行〜一人小走りで 1.6 $\sim 3.3 \mathrm{~Hz}$ と幅を持っている ${ }^{14)}$ 。そこで, 刻み時間を伸縮し, 卓越 振動数が $1.86 \mathrm{~Hz}$ の他に, $2.03 \mathrm{~Hz}, 1.66 \mathrm{~Hz}, 2.49 \mathrm{~Hz}$ の 4 通りの荷 重を与えた。これらは対象床梁（G0，G1，G2モデル）の固有振 動数の約1/2倍となる。これらを F0, F1, F2, F3荷重と表す。

・構造減衰：実測による結果 $\left.{ }^{15)}, 16\right)$ では, 床梁の減衰定数は概ね $1 \%$ 〜 $10 \%$ となりばらつきがあるが, ここでは一次固有振動数で $1 \%$ の初期剛性比例型とする。

・慣性質量：質量比として, 従来型 TMD 相当として0.01 (0.17464t), 本論の機構で無理なく実現できる值として0.05（0.8732t）， 0.1 （1.7464t）の3 ケースを設定する。付加減衰, ばね剛性はこの質 量比に対して後述の最適值を与えた。これらを D0, D1, D2ダン パーと表す。以上の解析パラメー夕の記号を表 4 にまとめる。 ・ボールねじ機構の内部減衰（摩擦・減衰係数）は表 2 とする。

・制振機構において, 制振効果を得るために必要な負荷減衰機構と して, 粘性減衰係数を与える。主架構（G0）と同調するための 付加剛性と粘性減衰係数は, 質量比に対して加速度応答倍率の 2 つのピークがほぼ等しくなるように, 式(3)を用いて数值的に求め, 設定した。制振機構の諸元を表 5 に示す。質量比が大きい場合の 減衰係数は表 2 の減衰係数よりも遙かに大きく, ボールねじ機構 の内部粘性減衰が解析結果に与える影響は小さいと考えられる。 制振機構無しの床に F0お よび F1荷重を入力した場合の加速度波 形, 制振機構ありの床に F1荷重を入力した場合の加速度波形を図
スラブ幅 $3.6 \mathrm{~m} 、 0.6 \mathrm{t} / \mathrm{m}^{2}$
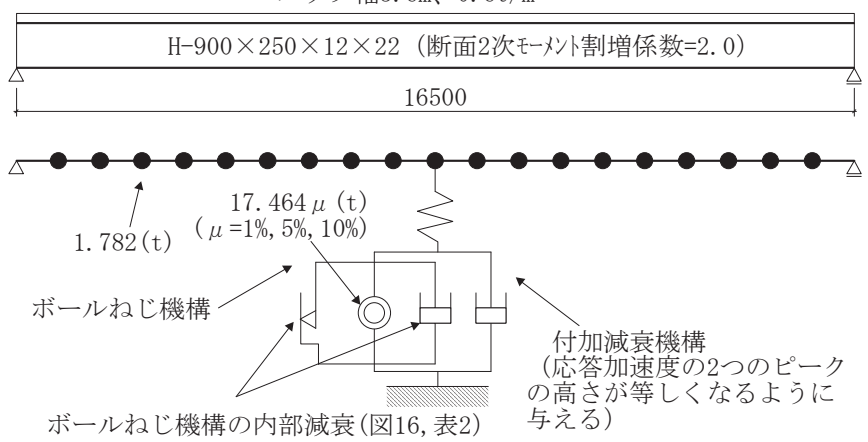

図21 スラブ付き梁と解析モデル

表 3 固有值解析結果

\begin{tabular}{|c|c|c|}
\hline 振動数 $(\mathrm{Hz})$ & 周期 $(\mathrm{s})$ & モード \\
\hline 4.07 & 0.246 & 鉛直 1 次 \\
\hline 15.2 & 0.0657 & 鉛直 2 次 \\
\hline 31.1 & 0.0321 & 鉛直 3 次 \\
\hline
\end{tabular}
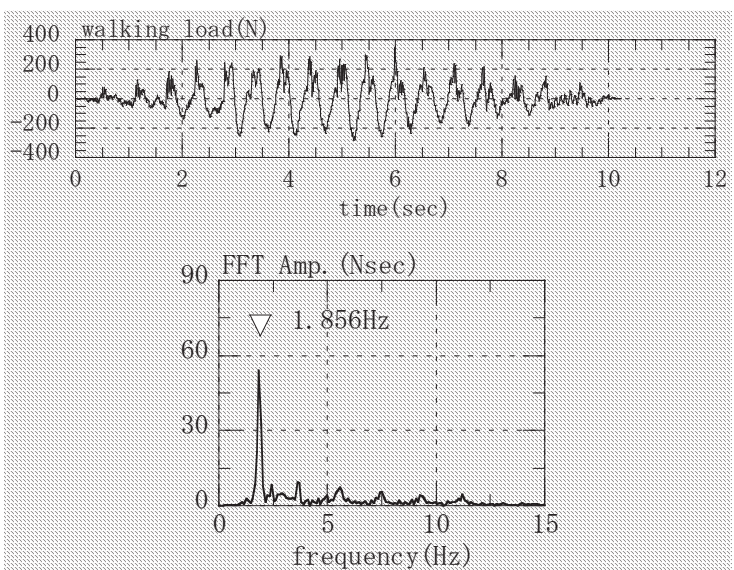

図22 歩行荷重の波形と Fourier 振幅

\begin{tabular}{|c|c|c|c|}
\hline 汤 & G0 & \multicolumn{2}{|c|}{ 標準（4.07Hz） } \\
\hline 田右坄㔚粉 & G1 & \multicolumn{2}{|c|}{ 剛性 $2 / 3$ 倍 $(3.32 \mathrm{~Hz})$} \\
\hline & G2 & \multicolumn{2}{|c|}{ 剛性 1.5 倍 $(4.98 \mathrm{~Hz})$} \\
\hline & F0 & \multicolumn{2}{|c|}{ 標準 (1.86Hz) } \\
\hline 荷重 & $\mathrm{F} 1$ & \multicolumn{2}{|c|}{ 2. $03 \mathrm{~Hz}$} \\
\hline （卓越振動数） & $\mathrm{F} 2$ & \multicolumn{2}{|c|}{ 1. $66 \mathrm{~Hz}$} \\
\hline & F3 & \multicolumn{2}{|c|}{ 2. $49 \mathrm{~Hz}$} \\
\hline \multirow{3}{*}{ 質量比 } & D0 & 0.01 & \multirow{3}{*}{$\begin{array}{l}\text { 付加剛性、 } \\
\text { 減衰は表 } 5\end{array}$} \\
\hline & D1 & 0.05 & \\
\hline & D2 & 0.1 & \\
\hline
\end{tabular}

表 5 制振機構の諸元

\begin{tabular}{|c|c|c|c|}
\hline & $\begin{array}{c}\text { 慣性質量 } \\
(\mathrm{t})\end{array}$ & $\begin{array}{c}\text { 付加減衰係数* } \\
(\mathrm{N} / \mathrm{m} / \mathrm{s})\end{array}$ & $\begin{array}{c}\text { 板ばね剛性 } \\
(\mathrm{N} / \mathrm{mm})\end{array}$ \\
\hline D0 & 0.17464 & 558.4 & 116.8 \\
\hline D1 & 0.8732 & 6730.4 & 636.2 \\
\hline D2 & 1.7464 & 21496.0 & 1457.2 \\
\hline \multicolumn{2}{|r|}{ *ボールねじ機構の内部粘性減衰を含む } \\
\hline
\end{tabular}



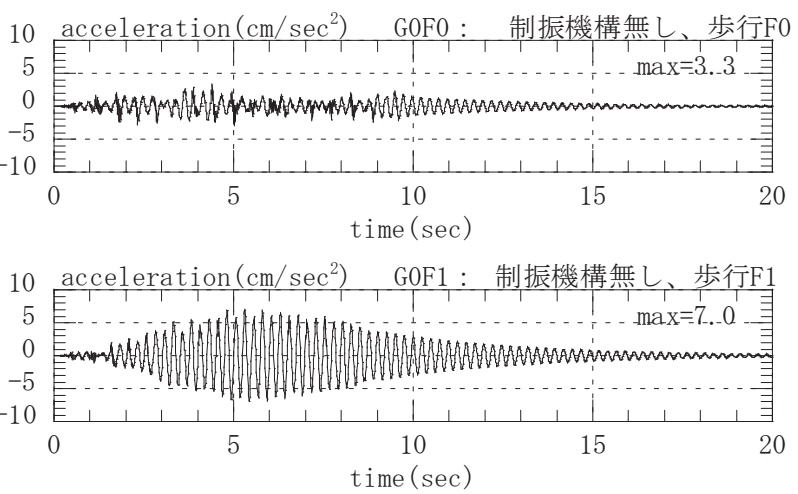

10 acceleration $\left(\mathrm{cm} / \mathrm{sec}^{2}\right)$ G0D0F1 : 制振機構有り $(\mu=1 \%)$ 歩行F1

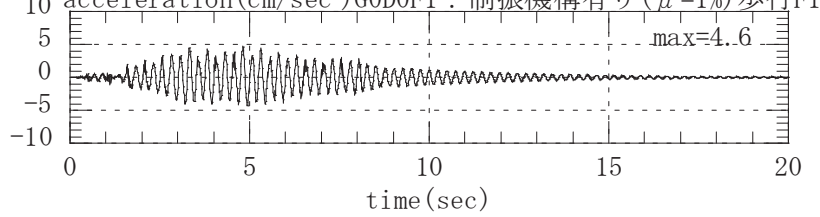

10 acceleration $\left(\mathrm{cm} / \mathrm{sec}^{2}\right) \mathrm{GOD} 1 \mathrm{~F} 1$ : 制振機構有り $(\mu=5 \%)$ 歩行F1

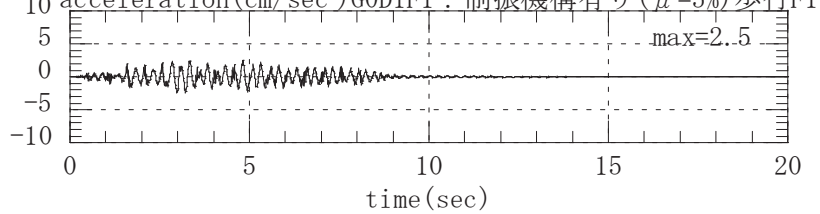

10 acceleration $\left(\mathrm{cm} / \mathrm{sec}^{2}\right) \mathrm{G} 0 \mathrm{D} 2 \mathrm{~F} 1$ ：制振機構有り $(\mu=10 \%)$ 歩行F1

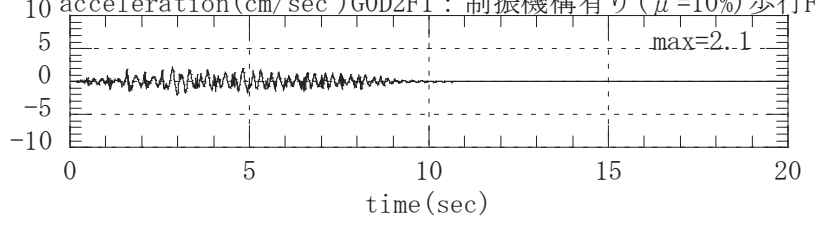

図23 床梁の加速度波形

23 に示す。制振機構がない場合, F0荷重では最大加速度は $3.3 \mathrm{~cm} /$ $\mathrm{sec}^{2}$ となっているが $(\mathrm{G} 0 \mathrm{~F} 0)$ ，わずかに歩調を速めた F1荷重では $7.0 \mathrm{~cm} / \mathrm{sec}^{2}$ となっている（G0F1）。制振機構を付けると最大加速度 はそれぞれ4.6，2.5，2.1cm/ $/ \mathrm{sec}^{2}$ となっている（G0D0F1，G0D1F1， G0D2F1)。これらの結果から, 床は固有振動数の $1 / 2$ の卓越振動数 を持つ荷重波形に共振し振幅が大きくなること, ダンパーによって 最大加速度が低減されること, 低減効果は質量比が大きいものほど 顕著であることがわかる。また，加振時間である 10 秒以後の応答の 比較から，制振機構によって後摇れが低減されていると言える。

解析結果の一覧を表 6 および図24に示す。図では荷重の種類にか かわらず各梁・各制振機構の場合に㧍ける最大加速度を示してい

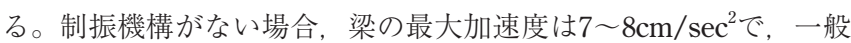
事務室の居住性としては大きな值を示している ${ }^{14)}$ 。質量比 $10 \%$ の制 振機構を付加すると, 床の固有振動数のばらつきや加振振動数のば らつきを考慮しても， $3 \mathrm{~cm} / \mathrm{sec}^{2}$ 程度となり，共振時の応答最大加 速度は大幅に低減されていることがわかる。なお，制振機構がない 場合の G2で，F3とともにF2の場合の応答が大きいのは，F3の卓 越振動数が床の振動数の $1 / 2$ 倍, F 2 の卓越振動数が $1 / 3$ 倍になって おり，ともに倍調波で共振していることに拠る。

\section{2 上下地震動に対する検討}

質量比0.1の制振機構を設置した梁の地震応答解析を行い, 制振 機構を持たない場合の応答と比較する。地震波は代表的な強震記録 である El Centro, Taft, 八戸, JMA 神戸の上下動（原波）であり，
表 6 実大梁の歩行解析最大加速度一覧 $\left(\mathrm{cm} / \mathrm{sec}^{2}\right)$

\begin{tabular}{|c|c|c|c|c|c|c|c|c|}
\hline \multirow{2}{*}{ 梁 } & \multicolumn{9}{|c|}{ 梁のみ } & \multicolumn{4}{|c|}{ D0 } \\
\cline { 2 - 9 } & F0 & F1 & F2 & F3 & F0 & F1 & F2 & F3 \\
\hline G0 & 3.3 & 7.0 & 3.8 & 4.6 & 3.2 & 4.6 & 3.6 & 4.4 \\
\hline G1 & 4.2 & 4.4 & 6.5 & 5.2 & 3.9 & 3.8 & 5.2 & 4.9 \\
\hline G2 & 5.4 & 3.3 & 8.1 & 7.4 & 5.2 & 3.3 & 6.8 & 6.4 \\
\hline \multirow{2}{*}{ 梁 } & \multicolumn{7}{|c|}{ D1 } & \multicolumn{5}{|c|}{ D2 } \\
\cline { 2 - 9 } & F0 & F1 & F2 & F3 & F0 & F1 & F2 & F3 \\
\hline G0 & 2.4 & 2.5 & 2.8 & 3.3 & 2.2 & 2.1 & 2.5 & 2.8 \\
\hline G1 & 2.9 & 3.3 & 3.0 & 4.0 & 2.5 & 2.8 & 2.2 & 3.7 \\
\hline G2 & 3.7 & 2.3 & 3.5 & 3.1 & 3.3 & 2.6 & 2.3 & 2.1 \\
\hline
\end{tabular}

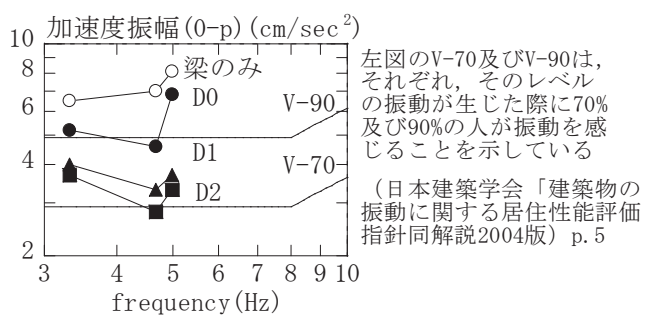

図24 各梁の最大加速度值
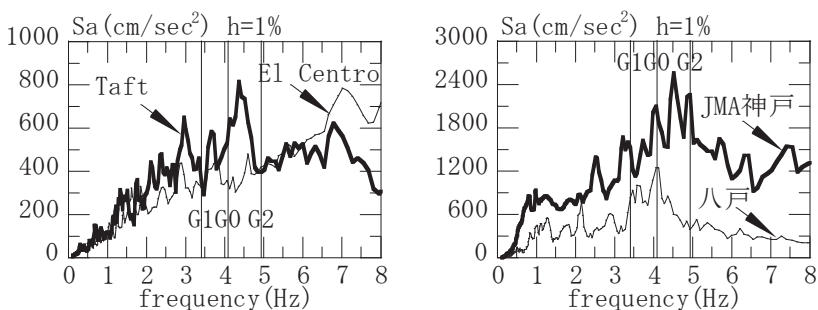

図25 代表的な強震記録の上下動の Fourier 振幅

図21のモデルの両端に入力した。データの継続時間は八戸が 30 秒, それ以外は 40 秒で, 解析はすべて40秒まで行った。また, 梁は弾性 としている。地震波の応答スペクトル（減衰 $1 \%$ ）を図 $25 に$ 示す。 図には各梁の固有振動数も示してある。

梁中央部の加速度波形の例（JMA 神戸と El Centro の原波, 制振 機構無しおよび有りの場合）と最大加速度の一覧をそれぞれ図26, 図27および表 7 に示す。最大加速度は地震動および梁の種類によっ て異なり，JMA 神戸が最も大きく，制振機構が無い場合には2000 $\mathrm{cm} / \mathrm{sec}^{2}$ 程度となる。制振機構を設置した場合には $1100 \mathrm{~cm} / \mathrm{sec}^{2}$ 程 度にまで低減している。一方, 最も応答が小さいのは El Centroの 場合で, 制振機構が無い場合には $400 \mathrm{~cm} / \mathrm{sec}^{2}$ 程度, 制振機構を設

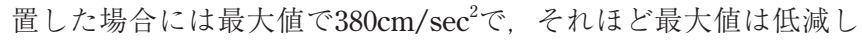
ていない。ただし，図27に示すとおり，これは局所的な值であり， 制振機構により，応答波形は全般的に低減されている。

最大加速度応答の低減率を表 8 に示す。応答低減率は地震動と梁 の固有振動数によってことなるが, 図 25 , 表 7 から, 応答が大きく なる場合, すなわち梁の固有振動数近傍の加速度応答スペクトルが 卓越するような場合には，より顕著な応答低減を示している。JMA 神戸および El Centroの応答波形を10秒区間ずつ用いて求めた Fourier 振幅を図28, 図29に示す。制振機構が無い梁では, JMA 神 戸の場合には 10 秒以降, El Centroの場合には30秒以降から応答は 収まってゆくが，その過程においても制振機構がある場合には，共 振成分の応答低減により, 応答をより小さなものにしていることが わかる。 


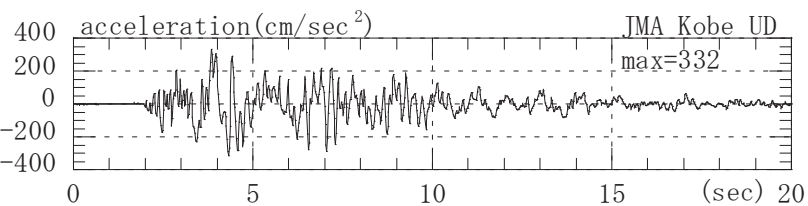

3000 acceleration $\left(\mathrm{cm} / \mathrm{sec}^{2}\right)$ G0K0 : F1oor No damp.

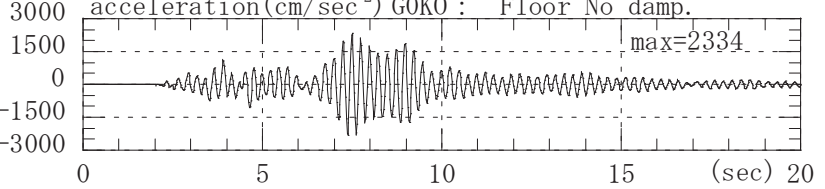

3000 acceleration $\left(\mathrm{cm} / \mathrm{sec}^{2}\right)$ G0D2K0 : Floor + damp. $(\mu=10 \%)$

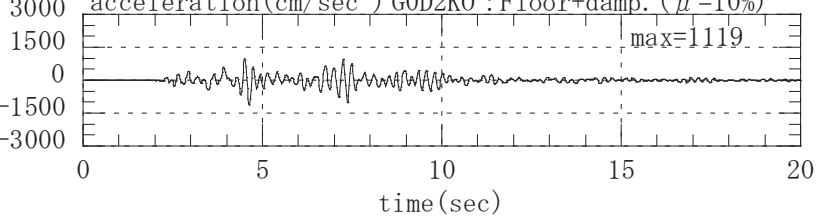

図26 JMA 神戸（原波）と床応答（制振機構無しと有り）
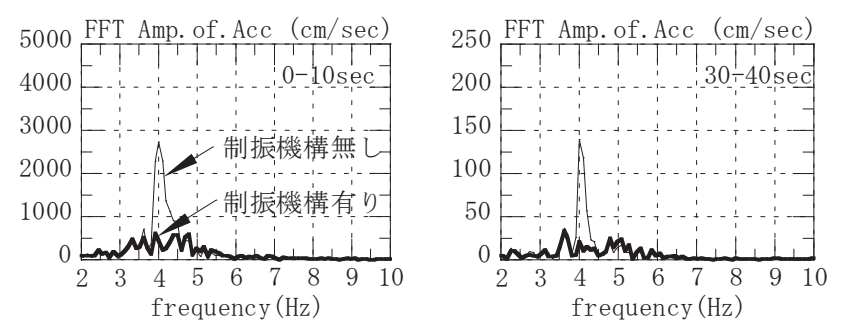

図28 JMA 神戸波床応答の Fourier 振幅

表 7 実大梁の地震応答解析最大加速度一覧 $\left(\mathrm{cm} / \mathrm{sec}^{2}\right)$

\begin{tabular}{|c|c|c|c|c|c|c|c|c|}
\hline \multirow{2}{*}{ 梁 } & \multicolumn{4}{|c|}{ 梁のみ } & \multicolumn{4}{|c|}{ \2 } \\
\cline { 2 - 10 } & EL & TA & HA & K0 & EL & TA & HA & K0 \\
\hline G0 & 400 & 700 & 1600 & 2330 & 380 & 250 & 330 & 1120 \\
\hline G1 & 440 & 560 & 860 & 1960 & 270 & 320 & 280 & 740 \\
\hline G2 & 550 & 530 & 480 & 2070 & 360 & 330 & 330 & 1130 \\
\hline
\end{tabular}

表 8 実大梁の地震応答解析の応答低減率

\begin{tabular}{|c|c|c|c|c|}
\hline \multirow{2}{*}{ 梁 } & \multicolumn{4}{|c|}{ D2 } \\
\cline { 2 - 5 } & EL & TA & HA & K0 \\
\hline G0 & 0.95 & 0.36 & 0.21 & 0.48 \\
\hline G1 & 0.61 & 0.57 & 0.33 & 0.38 \\
\hline G2 & 0.65 & 0.62 & 0.69 & 0.55 \\
\hline
\end{tabular}

\section{7. 結論と今後の課題}

本論では，回転慣性質量を利用して梁の上下振動の低減を図る機 構を提案し，実大ボールねじ機構を用いた加振実験を行い，その実 用性に関する検討を行った。本研究で得られた結論を以下に述べる。

1）ボールねじ機構を利用することで, 実質量が小さい錘でも大き な TMD 効果が得られることを実験によって確認した。

2）入力レベルが小さいと, ボールねじ機構の内部抵抗により, 制 振機構の共振が阻害される。

3）ボールねじ機構の内部抵抗を粘性減衰および摩擦によりモデル

化し，実験結果をよく説明しうる解析モデルを構築した。

4) 実大梁へ適用した場合のシミュレーション解析により, 本機構 では従来TMD に比べて非常に小さな実質量でも，質量比を大 きく設定することができ, 歩行共振時および地震時の応答加速 度を大幅に低減し得ることがわかった。

なお，実験ではボールねじ機構のみを設置し，減衰機構を設けて いない。減衰機構については今後の課題である。
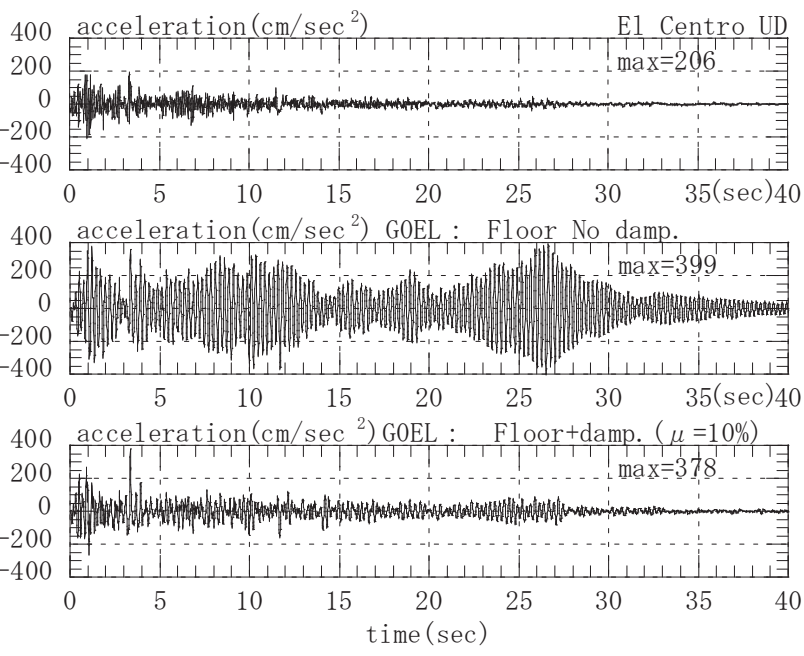

図27 El Centro（原波）と床応答（制振機構無しと有り）
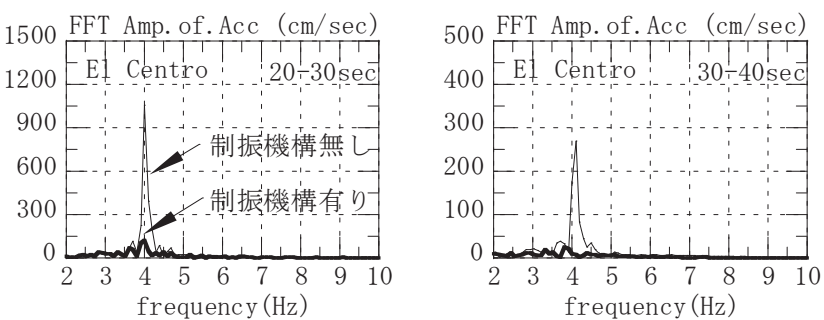

図29 El Centro 波床応答の Fourier 振幅

\section{参考文献}

1）小川, 沼野, 水本, 塩谷, 須賀川：粘弾性体を用いた上下動制振装置の 効果について - 実建物での地震観測記録 - , 日本建築学会大会学術講演 梗概集構造(1), pp.1013-1014, 1992.8

2）高橋, 片山, 吉岡, 今沢：床構造体の減衰性能に関する実験的研究（そ の 2 ) 動制振器を適用した実構造体における振動実験, 日本建築学会構 造系論文集第507号, pp.61-67, 1998.5

3）森田, 石丸, 木田, 佐藤, 藤森: 変形増幅機構を有する TMD の開発研 究建築学会技術報告集第25号, pp.91-, 2007.6

4）柴田, 袖山, 奥村ほか：慣性接続要素を用いた免制震装置の開発（その 1 〜その 4), 日本建築学会大会梗概集構造 B-2, pp.731-738, 2006.9

5）柳崎, 秦, 石丸, 古橋：DM 効果を利用した免震システムに関する基礎 的研究（その 1 〜の 2), 日本建築学会大会学術講演梗概集構造 B-2, pp.1041-1044, 2007.8

6）斉藤，栗田，井上：慣性接続要素を利用した線形粘性ダンパーによる一 質点構造の最適応答制御と Kelvin モデル化手法に関する考察, 構造工学 論文集 Vol. 53B，pp.53-66，2007.3

7) 斉藤, 中南, 木田, 井上：慣性接続要素と最適化された柔バネ要素と粘 性要素を有する一層応答制御システムの振動実験, 構造工学論文集 Vol. 54B, pp.623-634, 2008.3

8）斉藤, 井上：慣性接続要素を利用した粘性ダンパーをもつ制振構造の最 適応答制御に関する一考察, 日本建築学会技術報告集第 13 巻第 26 号, pp.457-462, 2007.12

9）松岡，大亦ほか：抵抗力拡大機構を用いた磁気ダンパ弾性支持法に関す る研究，日本機械学会論文集 C 編，72巻716号，pp.1056-1063，2006.4

10）関根, 栗田：制振構造システムにおける慣性接続要素を用いた粘弾性ダ ンパーの最適設計に関する基礎的研究, 日本建築学会大会学術講演梗概 集構造 B-2, pp.641-642,2008.9

11）大崎順彦：地震動のスペクトル解析入門，鹿島出版会，昭和60年 2 月

12）古橋, 石丸：慣性接続要素によるモード分離, 日本建築学会構造系論文 集第576号, pp.55-62, 2004.2

13）塩谷, 早川：人の歩行による動的加重の時刻歴モデル (その 1 , その 2 ), 日本建築学会大会学術講演梗概集構造(1), pp.77-80, 1995.8

14）日本建築学会 : 居住性能に関する環境振動評価の現状と規準, pp.29, 2000.6

15）内田, 桐原, 青柳, 川村：床ばりの振動性状に関する研究（その 1 実測 結果), 日本建築学会大会学術講演梗概集, pp.827-828, 昭和53年 9 月

16）櫛田：床の振動性状と最適環境を考慮した設計法に関する研究一床振動評 価基準に関する考察, 日本建築学会計画系論文集第404号, pp.1-7, 1989.10 